\title{
Expanding HIV/AIDS care service sites: a cross sectional survey of community pharmacists' views in South-East, Nigeria
}

\author{
Nnenna Ajagu, Maureen Ugonwa Anetoh and Sunday Odunke Nduka*
}

\begin{abstract}
Background: Community pharmacists are very accessible to most patients yet; they have been underutilized in the aspect of providing HIV care and services. The World Health Organisation recently recommended expanding community pharmacists' roles to address the increasing complexity of antiretroviral agents and co-infection drug regimen. This study therefore was designed to assess the readiness and willingness of community pharmacists in Nigeria to participate in the care of people living with HIV/AIDS and the possible inclusion of their pharmacy premises as sites for HIV care services.

Methods: A descriptive cross sectional survey was carried out among 205 community pharmacists in south east, Nigeria between October, 2016 and February, 2017. Two hundred and five self-administered questionnaires were distributed to conveniently selected community pharmacists in the region. Data collected were analysed using SPSS version 23. Descriptive statistics was conducted for the demographics and percentage mean scores for each domain were computed. The variables in each domain were categorised into groups and simple percentages were used to show the percentage distribution of the variables. Cross tabulation was also carried out to show the relationship between the variables and groups' differences were explored using analysis of variance and $P$-values $<0.05$ were considered significant.
\end{abstract}

Results: All distributed questionnaires were filled and retrieved. The overall knowledge of HIV among the surveyed pharmacists was seen to be high (70.41\%). Although the percentage attitude score of the respondents towards HIV care services was on the average (57\%), they were highly willing and ready to use their premise to offer HIV services with a percentage mean readiness score of $87.32 \%$. However, their perceived skills in carrying out these services were observed to be low.

Conclusion: Community pharmacists in the south eastern part of Nigeria have high knowledge of HIV and a somewhat attitude towards HIV care services with high willingness and readiness to be involved in HIV care and services. Despite efforts to engage community pharmacists in HIV services more is needed in the aspect of making adequate policies to further empower more community pharmacists in this aspect of care.

Keywords: Community pharmacists, HIV services sites, Attitude, Willingness and readiness

\footnotetext{
* Correspondence: so.nduka@unizik.edu.ng

Department of Clinical Pharmacy and Pharmacy Management, Faculty of

Pharmaceutical Sciences, Nnamdi Azikiwe University, Awka, Anambra State,

Nigeria
} 


\section{Background}

HIV infection continues to be a major global public health concern having claimed more than 35 million people worldwide [1] mostly in the developing countries and sub-Saharan Africa in particular [2]. Voluntary counseling and testing together with access to antiretroviral agents have been identified as the key strategies in HIV/AIDS prevention and survival of infected individuals [3]. Expanding universal access to these strategies are therefore, the critical steps to achieving HIV/AIDS vision 2020 which aim to end the AIDS epidemic by 2030 [4].

Effective implementation of these critical steps have been hindered by some factors including accessibility of facilities, high cost of transportation to the clinics, long waiting times and lack of flexibility of HIV clinics among others [5]. Of about 36.9 million people living with HIV/ AIDS (PLWHA) globally, an estimate of $42.8 \%$ had access to antiretroviral therapy in 2014 [6]. Sub-Saharan Africa which account for about $71 \%$ of the global estimate of PLWHA had 37\% access and Nigeria only 22\% with just about 740,000 out of 3.4 million infected people currently under treatment [6, 7]. Furthermore, only about $54 \%$ of people with HIV worldwide know their status with little number recorded in low- and middle-income countries [8]. According to UNAIDS, about $95 \%$ of HIV service delivery takes place in the Hospitals [9]. The World Health Organization drawing on the Cochrane Review results recommended initiating HIV care and services at peripheral clinics and in community settings [10] as part of the strategies needed to close the HIV testing and counseling gap especially in sub-Saharan Africa [11]. This strategy involves the decentralization of HIV services from hospitals to more peripheral health facilities [10]. Community pharmacy settings have been recognized as effective sites for health promotion, screening and chronic diseases management [12] and could effectively be utilized in the decentralization strategy. Thus, WHO recommended expanding the roles of community pharmacists to increase access to HIV services [13]. A cross sectional survey of 207 randomly selected community pharmacists in Pune, India between 2004 and 2005 showed a low knowledge and poor attitude towards HIV infected patients but a high willingness to participate in the provision of care to HIV infected persons [14]. Another study in Spain that randomly surveyed the use of HIV rapid screening tests in 20 pharmacies also showed that patients reported that the convenience and accessibility of community pharmacies were significant motivators for their decision to get tested [15]. Recently, the Pharmaceutical Society of Nigeria (PSN) president signed a memorandum of understanding on strengthening integrated delivery services on HIV/AIDS with Howard University Pace Centre (HUPACE) in Nigeria where he highlighted that the community pharmacists will be involved with testing, counseling, care support services and distribution of antiretroviral agents. Although a model for community pharmacists' involvement in HIV/AIDS services has been proposed in Nigeria [16], there is still need to access the community pharmacists' readiness and level of interest in these services. This study therefore, was designed to access the readiness and willingness of community pharmacists in South east, Nigeria to participate in HIV care and services. The study further evaluated the pharmacists' knowledge, attitude and skills with their present level of involvement in these services.

\section{Methods}

\section{Study population and study design}

The study is a cross sectional study carried out among registered community pharmacists in the South east states of Nigeria between October, 2016 and February, 2017. The South east Nigeria is one of the 6 geopolitical zones in Nigeria and mainly, the indigenous homeland of the Igbo ethnic group [17]. It is made up of 5 states namely; Anambra, Abia, Imo, Enugu, and Ebonyi states. According to the 2006 population census in Nigeria, this zone has an estimated population of about 16,381,729 people [18]. In addition to the numerous health institutions in the zone including primary, secondary and tertiary health institutions, community pharmacies and community pharmacists forms major part of healthcare facilities and key health care personnel in this zone [19].

According to the information from the various state offices of the Pharmacists Council of Nigeria (PCN) in the region, there were about 441 registered community pharmacists (98 in Anambra state, 103 in Imo state, 125 in Enugu state, 41 in Ebonyi state and 74 in Abia state) in south east Nigeria as at the time of carrying out the study. Using the number of community pharmacists registered in each state and assuming a confidence level of $95 \%$ with a confidence interval of $+/-12$ in each case, a sample size of 35 for Abia state, 40 for Anambara state, 44 for Enugu state, 26 for Ebonyi state and 41 for Imo state with a total number of 186 were deemed appropriate for the study [20]. An additional $10 \%$ of the total calculated sample size (186) distributed in the ratio of 2:3:3:1:2 to Anambra, Imo, Enugu, Ebonyi and Abia states respectively with an extra one respondent added to Enugu state were included to accommodate nonusable questionnaires due to improper filling.

A total of 205 questionnaires were conveniently distributed in the zone as follows: Abia state, 38; Anambra state, 43; Enugu state, 50; Ebonyi state, 28 and Imo state, 46.

The state chairman of Association of Community Pharmacists of Nigeria (ACPN) in each of the five states was contacted to find out their respective dates for 2016 annual general meeting. The annual general meeting day 
was considered and used because virtually all members of the association will be in attendance. Using the estimated sample size from each state, questionnaires were distributed to selected members in attendance that orally consented until the projected number in the state was reached. Therefore, a total of 205 questionnaires were distributed and retrieved throughout the 5 states. The inclusion criteria are registered community pharmacists who are currently practicing while pharmacists practicing in other sectors and intern pharmacists are excluded from the study.

\section{Research instrument and validation}

A 31-item self-administered questionnaire was developed, validated and used for the study (Additional file 1). The questionnaire was developed by reviewing various documents on HIV/AIDS and previous published works [14, 21-25].

The instrument was structured to consist of four different sections. The first section included sociodemographic characteristics. The second section consisted of seven questions that assessed respondents' knowledge of HIV and antiretroviral agents (ARVs). Section three contained information used to evaluate the community pharmacists' attitude and present involvement in HIV care and services. This section consisted of ten questions, with three questions making up the attitude domain and that of involvement constituting seven questions. The last section (section 4) assessed readiness and their perceived skills in HIV services. Four questions assessed readiness while five questions assessed their perceived skills.

The survey instrument was independently face validated by three pharmacy lecturers in the department of Clinical Pharmacy and Pharmacy Management, Nnamdi Azikiwe University, Awka, two Hospital Pharmacists specially trained in the care of HIV-infected patients and one Family Health International (fhi360) staff in Anambra state. The instrument was then, pilot tested to assess its feasibility in Asaba, Delta state. Asaba is the capital of Delta state which is one of the states in the Southsouth geopolitical zone of Nigeria. It has common boundaries with Anambra state and has a cluster of community pharmacies and a good number of pharmacists. The questionnaire was distributed to 15 community pharmacists after getting their consent. Retrieved questionnaires were coded, entered into SPSS 23 and the internal consistency of the questions was checked using Cronbach's alpha (CA) with an alpha value of $\geq 0.70$ considered reliable. The corrected item-total correlation of each item was calculated and items with a corrected item-total correlation value of $\geq 0.3$ were retained. The result from the pilot was used to modify the questionnaire to further improve the instrument.
During the modification, a total of seven questions were deleted and questions especially in the skills section changed from a ranged question to a "Yes" or "No" response.

\section{Ethical consideration}

Ethical approval was obtained from the ethics committee of Nnamdi Azikiwe University Teaching Hospital, Nnewi, Anambra state, Nigeria with approval number, NAUTH/CS/VOL.9/132/2016/106. The study secured oral informed consent from the respondents. Anonymity of participants' data was maintained by not including participants' name, name and address of their pharmacies.

\section{Data analysis}

Retrieved copies of the questionnaire were collected and classified into domains. Each domain was coded and entered into excel spread sheet and analysed using SPSS version 23. Descriptive statistics was conducted for the demographics and percentage mean scores for each domain were computed. The variables in each domain were categorised into groups and simple percentages. Cross tabulation was also carried out to show the relationship between the variables. The groups' differences were explored using analysis of variance (ANOVA) at $P<0.05$.

The knowledge domain consisted of 15 expanded items with 'yes' or 'no' responses, some of which were negatively worded. Each correctly answered item was scored ' 1 ' and ' 0 ' if otherwise, giving possible minimum and maximum sum total scores of 0 and 15 for knowledge. The total correct answers were transformed into percentage knowledge scores. For ease of comparison, the knowledge status were divided into 'low', 'moderate' and 'high' knowledge based on their percentage scores. Respondents who scored below 50 were categorized as having low knowledge, respondents who scored between 50.00 and 69.99 were categorized as having moderate knowledge while respondents who had equal or greater than 70 were categorized as having high knowledge.

The involvement domain consisted of 9 expanded items with 'Yes' or 'No' responses, where a 'Yes' response indicated 'involved' and a 'No' indicated 'not involved'. Each item activity where the respondent was involved was scored ' 1 ' and ' 0 ' if otherwise, giving possible minimum and maximum sum total scores of 0 and 9 involvement domain respectively. The total score of involvement was transformed into percentage involvement scores. For ease of comparison, the involvement status were further divided into 'low', 'moderate' and 'high' involvement based on their percentage scores. Respondents who scored below 50 were categorized as having low involvement, respondents who scored between 50.00 and 69.99 were categorized as having moderate 
involvement while respondents who had equal or greater than 70 were categorized as having high involvement.

The attitude domain comprised 5 items with 5 -likert scale of 'strongly disagree, disagree, undecided, agree and strongly agree'. The strongly disagree was scored ' 0 ', disagree ' 1 ', undecided ' 2 ', agree ' 3 ' and strongly agree ' 4 '. The items were worded to reflect 'negative' to 'positive' attitude when responses from 'strongly disagree' to 'strongly agree' were selected. This gave possible minimum and maximum sum total scores of 0 and 20 for attitude respectively. These total scores were transformed into percentage attitude scores. For ease of comparison, the attitude status was divided into 'negative' and 'positive' based on the percentage mean attitude scores. Respondents who scored below the mean were categorized as having negative attitude while respondents who had equal or greater than the mean were categorized as having positive attitude.

The readiness domain consisted of 4 items with 'Yes' response indicating 'ready' and a 'No' response indicating 'not ready'. Readiness was scored ' 1 ' and ' 0 ' if otherwise, given possible minimum and maximum sum total scores of 0 and 4 for readiness. The total scores were transformed into percentage readiness scores. For ease of comparison, the readiness status were divided into 'low', 'moderate' and 'high' readiness based on their percentage scores, respondents who scored below 50 were categorized as having low readiness, respondents who scored between 50.00 and 69.99 were categorized as having moderately ready while respondents who had equal or greater than 70 were categorized as being highly ready.

The perceived skill domain consisted of 5 items with 'Skilled' or 'not skilled' responses. Skilled response was scored ' 1 ' and ' 0 ' if otherwise, given possible minimum and maximum sum total scores of 0 and 5 for skill. The total scores were transformed into percentage skill scores. For ease of comparison, the skill status were divided into 'low', 'moderate' and 'high' knowledge based on their percentage scores, respondents who scored below 50 were categorized as having low skill, respondents who scored between 50.00 and 69.99 were categorized as having moderate skill while respondents who had equal or greater than 70 were categorized as being highly skilled.

\section{Result}

The demographic characteristics of the respondents (Table 1) showed that majority of the community pharmacists were male (61\%) with more than half of them within the age range of 31-50 years. While most of the pharmacists $(52.7 \%)$ have $\leq 10$ years of experience, a good number of them (63.4\%) have about 5 or less than five employees in their premises.
Table 1 Demographic characteristics of respondents

\begin{tabular}{ll}
\hline Variable & Frequency (\%) \\
\hline Gender & \\
Male & $125(61.0)$ \\
Female & $80(39.0)$ \\
Age & \\
$\leq 30$ & $23(11.2)$ \\
$31-40$ & $80(39.0)$ \\
$41-50$ & $46(22.4)$ \\
$51-60$ & $38(18.5)$ \\
$\geq 60$ & $18(18.8)$ \\
Number of employees & \\
$\leq 5$ & $130(63.4)$ \\
$6-10$ & $60(29.3)$ \\
$11-15$ & $7(3.4)$ \\
$>16$ & $8(3.9)$ \\
Years of practice & \\
$<5$ & $49(23.9)$ \\
$5-10$ & $59(28.8)$ \\
$11-15$ & $31(15.5)$ \\
$16-20$ & $14(6.8)$ \\
$>20$ & $52(25.4)$ \\
Qualifications & \\
M. Pharm & $128(62.4)$ \\
Pharm.D & $48(23.4)$ \\
MBA & $23(11.2)$ \\
\hline & $3(1.5)$ \\
\hline &
\end{tabular}

Item analysis of the community pharmacists' responses to HIV and HIV services are shown in Table 2. The pharmacists showed a very good knowledge of HIV with a percentage mean score of $70.41 \%$. While majority of the respondents were able to get most questions to HIV knowledge, $70.2 \%$ did not seem to understand the WHO clinical staging of this disease. A large number of the respondents (96.6\%) showed a positive attitude towards community pharmacists' role(s) in the provision of HIV services with about two-third (62.9\%) showing willingness for the use of their premises for the provision of these services. However, the percentage mean attitude score of the respondents was $57.0 \%$. With a mean involvement score of $36.72 \%$, the surveyed community pharmacists' were seen not to be currently involved in HIV services as more than two-third revealed that they do not encounter HIV clients in their premises. Although most community pharmacists stock condoms (90.7\%), just very few of them stock HIV test kits (23.4\%) and antiretroviral agents (31.7\%). Assessment of 
Table 2 Respondents assessment

\begin{tabular}{|c|c|c|}
\hline \multirow{2}{*}{$\frac{\text { Variable }}{\text { Knowledge }}$} & \multicolumn{2}{|c|}{ Response (\%) } \\
\hline & Wrong & Correct \\
\hline \multicolumn{3}{|l|}{ Goal(s) for HIV therapy } \\
\hline Prolongation of quality of life & $23(11.2)$ & $182(88.8)$ \\
\hline Achievement of immune reconstitution & $74(36.1)$ & $131(63.9)$ \\
\hline Reduction in HIV transmission & $41(20.0)$ & $164(80.0)$ \\
\hline Reduction in viral load & $35(17.1)$ & $170(82.9)$ \\
\hline \multicolumn{3}{|l|}{ Criteria for initiating HAART } \\
\hline CD4 level 500 or below & $46(23.9)$ & $159(76.1)$ \\
\hline $\begin{array}{l}\text { WHO Stage } 3 \text { and } 4 \text { irrespective } \\
\text { of CD4 count }\end{array}$ & 79 (38.9) & $126(61.5)$ \\
\hline Co-existing TB Infection & $86(42.0)$ & $119(58.0)$ \\
\hline $\begin{array}{l}\text { Understanding of the WHO clinical } \\
\text { staging of HIV/AID }\end{array}$ & $144(70.2)$ & $61(29.8)$ \\
\hline $\begin{array}{l}\text { Minimum number of ARVs that should } \\
\text { be included in an ideal regimen }\end{array}$ & $51(24.9)$ & $154(75.1)$ \\
\hline \multicolumn{3}{|c|}{ Approved combination of ARVs used in HAART regimen } \\
\hline Efavirenz + Lamivudine + Tenofovir & $73(35.6)$ & $132(64.4)$ \\
\hline Abacavir + Lamivudine + Efavirenz & $112(54.6)$ & $93(45.4)$ \\
\hline $\begin{array}{l}\text { Lopinavir/ritonavir + Lamuvidine } \\
\text { +Zidovudine }\end{array}$ & $82(40.0)$ & $123(60)$ \\
\hline $\begin{array}{l}\text { Zidovudine + Lamuvudine } \\
+ \text { Emtricitabine }\end{array}$ & $27(13.2)$ & $178(86.8)$ \\
\hline Drug added as booster to Lopinavir & $95(46.3)$ & $110(53.7)$ \\
\hline Ideal storage condition for ARV & $54(26.3)$ & $151(73.7)$ \\
\hline \multicolumn{3}{|c|}{ Percentage mean knowledge score $=70.41 \pm S D$ (19.09) } \\
\hline Involvement & Involved & Not Involved \\
\hline HIV clients encounter in your premise & $48(23.4)$ & $156(76.1)$ \\
\hline $\begin{array}{l}\text { Activities with HIV clients in your } \\
\text { premise }\end{array}$ & $47(22.9)$ & $157(76.6)$ \\
\hline $\begin{array}{l}\text { Activities with suspected HIV clients } \\
\text { in your premise }\end{array}$ & $34(16.6)$ & $170(82.9)$ \\
\hline $\begin{array}{l}\text { Educate, counsel and reassure the } \\
\text { patient }\end{array}$ & $59(28.8)$ & $144(70.2)$ \\
\hline $\begin{array}{l}\text { Manage the patient for other } \\
\text { associated minor conditions } \\
\text { and document }\end{array}$ & $8(3.9)$ & $195(95.1)$ \\
\hline Refer patient to hospital & $143(69.8)$ & $60(29.3)$ \\
\hline Stock HIV test kit & $48(23.4)$ & $157(76.6)$ \\
\hline Stock ARVs & $65(31.7)$ & $140(68.3)$ \\
\hline Stock Condoms & $186(90.7)$ & $19(9.3)$ \\
\hline \multicolumn{3}{|c|}{ Percentage mean involvement score $=36.72 \pm S D$ (17.34) } \\
\hline Attitude & $\begin{array}{l}\text { Positive } \\
\text { attitude }\end{array}$ & $\begin{array}{l}\text { Negative } \\
\text { attitude }\end{array}$ \\
\hline $\begin{array}{l}\text { Community pharmacist have a role } \\
\text { to play in provision of HIV/AIDS } \\
\text { Services }\end{array}$ & $198(96.6)$ & $7(3.4)$ \\
\hline Willingness to use your premise & $129(62.9)$ & $75(36.6)$ \\
\hline
\end{tabular}

Table 2 Respondents assessment (Continued)

\begin{tabular}{|c|c|c|}
\hline Variable & \multicolumn{2}{|c|}{ Response (\%) } \\
\hline \multicolumn{3}{|l|}{$\begin{array}{l}\text { Factor that will enhance willingness } \\
\text { to offer HIV services }\end{array}$} \\
\hline $\begin{array}{l}\text { Training and sensitization lectures } \\
\text { are necessary to enhance community } \\
\text { pharmacists involvement in HIV/AIDS } \\
\text { care }\end{array}$ & $182(88.8)$ & $22(10.7)$ \\
\hline Payment/remuneration & $104(50.7)$ & $100(48.8)$ \\
\hline other incentives & $62(30.2)$ & $142(69.3)$ \\
\hline \multicolumn{3}{|c|}{ Percentage mean Attitude score $=56.98 \pm$ SD (19.67) } \\
\hline Readiness & Ready & Not ready \\
\hline Functional backup generator & $194(94.6)$ & $11(5.4)$ \\
\hline Counseling section & $199(97.1)$ & $6(2.9)$ \\
\hline $\begin{array}{l}\text { Counseling section with auditory } \\
\text { and visual privacy }\end{array}$ & $155(77.5)$ & $50(22.5)$ \\
\hline $\begin{array}{l}\text { Use of Patient information } \\
\text { sheet/book }\end{array}$ & $136(66.6)$ & $69(33.7)$ \\
\hline \multicolumn{3}{|c|}{ Percentage mean readiness score $=87.32 \pm S D(15.34)$} \\
\hline Perceived Skill & Not Skilled & Skilled \\
\hline $\begin{array}{l}\text { Educating target population } \\
\text { on HIV }\end{array}$ & $112(54.6)$ & $92(44.9)$ \\
\hline $\begin{array}{l}\text { Demonstrable skill on how to } \\
\text { carry out HIV rapid test }\end{array}$ & $150(73.2)$ & $54(26.3)$ \\
\hline $\begin{array}{l}\text { Counselling on importance of } \\
\text { adherence to HIV medication }\end{array}$ & $117(57.1)$ & $87(42.4)$ \\
\hline Referral of HIV client for care & $123(60.0)$ & $81(39.5)$ \\
\hline $\begin{array}{l}\text { HIV care and documentation } \\
\text { and reporting }\end{array}$ & $144(70.2)$ & $61(29.8)$ \\
\hline \multicolumn{3}{|c|}{ Percentage mean skill score $=39.26 \pm$ SD (38.13) } \\
\hline
\end{tabular}

community pharmacists readiness to offer HIV services gave a mean response score of $87.32 \%$ with majority (>90\%) having backup generator and counselling section/room. The community pharmacists perceived skill score in carrying out HIV/AIDS services was poor with a percentage mean score of $39.26 \%$.

The impact of demographic characteristics on HIV knowledge of the respondents is shown in Table 3. A one way between groups analysis of variance with knowledge divided into low, middle and high knowledge levels showed a statistical significant difference at the $p<0.001$ for the demographic characteristics $\mathrm{F}(4,200)=5.23, p<0.001$ with a moderate effect size (0.09). Independent t-test analysis indicated that the mean knowledge score for the female gen$\operatorname{der}(M=70.13 \pm \mathrm{SD}(70.93)$ was not significantly different from that of the male $(M=68.67 \pm S D(17.67)$. On the age distribution, post hoc analysis using Dennett's test indicated that the mean knowledge score for $>60$ years age group $(M=58.33 \pm \mathrm{SD}(24.27)$ was significantly different from those of $31-40$ years $(M=75.69 \pm \mathrm{SD}(17.89$, $p<0.001)$ and $45-50$ years $(\mathrm{M}=73.19 \pm \mathrm{SD}(17.06)$, $p=0.01$ ) but not significantly different from the others. 
Table 3 Knowledge of respondents based on demographic characteristics

\begin{tabular}{|c|c|c|c|c|c|c|c|}
\hline Demographic characteristics & $\begin{array}{l}\text { Low knowledge } \\
\text { n (\%) }\end{array}$ & $\begin{array}{l}\text { Moderate knowledge } \\
\text { n (\%) }\end{array}$ & $\begin{array}{l}\text { High knowledge } \\
\text { n (\%) }\end{array}$ & Mean & Std. deviation & Std. error & $P$ value \\
\hline \multicolumn{8}{|l|}{ Gender } \\
\hline Male & $23(65.7)$ & $38(30.4)$ & $64(56.6)$ & 68.67 & 17.67 & 1.58 & $0.12^{\mathrm{a}}$ \\
\hline Female & $12(34.3)$ & 19 (33.3) & $49(43.4)$ & 73.13 & 20.93 & 2.34 & \\
\hline \multicolumn{8}{|l|}{ Age (Years) } \\
\hline$\leq 30$ & $5(14.3)$ & $6(10.5)$ & $12(10.6)$ & 64.98 & 23.21 & 4.81 & $0.53^{b}$ \\
\hline $31-40$ & $10(28.6)$ & $16(28.1)$ & $54(47.8)$ & 75.69 & 17.89 & 2.00 & $<0.001^{\mathrm{b}}$ \\
\hline $41-50$ & $5(14.3)$ & $14(24.6)$ & $27(23.9)$ & 73.19 & 17.06 & 2.52 & $0.01^{b}$ \\
\hline $51-60$ & $6(17.1)$ & 19 (33.3) & $13(11.5)$ & 64.91 & 13.98 & 2.27 & $0.46^{\mathrm{b}}$ \\
\hline$\geq 61$ & $9(25.7)$ & $2(3.5)$ & $7(6.2)$ & 58.33 & 24.27 & 5.72 & Referent \\
\hline \multicolumn{8}{|l|}{ Number of employees } \\
\hline$\leq 5$ staff & $30(85.7)$ & $36(63.2)$ & $64(56.6)$ & 66.45 & 19.21 & 1.68 & $0.77^{b}$ \\
\hline $6-10$ staff & $4(11.4)$ & 18 (31.6) & 38 (33.6) & 77.59 & 16.27 & 2.10 & $0.55^{\mathrm{b}}$ \\
\hline 11-15 staff & $0(0.0)$ & $1(1.8)$ & $6(5.3)$ & 81.75 & 12.30 & 4.65 & $0.44^{\mathrm{b}}$ \\
\hline$\geq 15$ staff & $1(2.9)$ & $2(3.5)$ & $5(4.4)$ & 70.83 & 24.44 & 8.64 & Referent \\
\hline \multicolumn{8}{|l|}{ Years of Practice (Years) } \\
\hline$\leq 5$ & $12(34.3)$ & $13(22.8)$ & $24(21.2)$ & 64.83 & 23.44 & 3.35 & $0.99^{b}$ \\
\hline $6-10$ & $3(8.6)$ & $12(21.1)$ & $44(38.9)$ & 78.63 & 14.55 & 1.89 & $<0.001^{\mathrm{b}}$ \\
\hline $11-15$ & $5(14.3)$ & $10(17.5)$ & $16(14.2)$ & 17.15 & 17.00 & 3.05 & $0.28^{\mathrm{b}}$ \\
\hline $16-19$ & $0(0.0)$ & $4(7.0)$ & $10(8.8)$ & 76.98 & 10.42 & 2.78 & $0.07^{b}$ \\
\hline$\geq 20$ & $15(42.9)$ & $18(31.6)$ & $19(16.8)$ & 64.10 & 18.49 & 2.56 & Referent \\
\hline \multicolumn{8}{|l|}{ Qualification(s) } \\
\hline B. Pharm & $32(91.4)$ & $40(70.2)$ & $56(49.6)$ & 64.83 & 18.59 & 1.64 & $0.27^{b}$ \\
\hline M. Pharm & $3(8.6)$ & $15(26.6)$ & $30(26.5)$ & 73.94 & 16.21 & 2.34 & $0.85^{b}$ \\
\hline Pharm. D & $0(0.0)$ & $1(1.8)$ & $22(19.5)$ & 90.33 & 9.95 & 2.07 & $0.54^{b}$ \\
\hline FPC. Pharm & $0(0.0)$ & $0(0.0)$ & $3(2.7)$ & 88.89 & 5.56 & 3.21 & $0.78^{b}$ \\
\hline MBA & $0(0.0)$ & $1(1.8)$ & $2(1.8)$ & 79.62 & 21.03 & 12.14 & Referent \\
\hline
\end{tabular}

${ }^{\mathrm{a}}$ t-test was applied, ${ }^{\mathrm{b}}$ Dunnet test was applied, $n=205$

Similarly, comparison of knowledge level and respondents years of practice using $20 \mathrm{yrs}$. of practice as referent indicated a significant mean knowledge difference between the referent group and those of $6-10$ years in practice $(p<0.001)$.

The impact of demographic characteristics on the respondents' level of involvement in HIV/AIDS activities in their community pharmacies are presented in Table 4 with the involvement level grouped into low, moderate and high involvement with a statistical significant difference seen at $p=0.039$ for the demographic characteristics $F(4,197)=2.57, p<0.039$. However, the actual difference in mean scores between groups calculated from the eta squared was quite small (0.04). Whereas no significant difference was seen between the mean involvement scores of the male and female gender $(p>0.05)$, significant difference was seen between the mean involvement score for the referent age group $(M=25.25 \pm \mathrm{SD}(16.95)$ and the other age groups. Post hoc analysis indicated a significant difference between the involvement mean score for those with MBA $(\mathrm{M}=69.69, \pm \mathrm{SD}(21.00)$ and those with B.Pharm $(\mathrm{M}=35.85 \pm \mathrm{SD}(16.76), p<0.001)$, M.Pharm $(\mathrm{M}=41.67 \pm \mathrm{SD}(17.27), p=0.01)$ and Pharm $\mathrm{D}(\mathrm{M}=26.48 \pm \mathrm{SD}(12.53), p<0.001)$.

On the assessment of respondents attitudes based on demographic characteristics (Table 5), more male than female showed positive attitude towards HIV/AIDS care and services in the community pharmacies with respective mean scores of $58.94 \pm \mathrm{SD}(20.05)$ and $53.95 \pm \mathrm{SD}(18.79)$. However, their difference was not significant $(p>0.05)$. About $25 \%$ of the respondents with less than 5 years of practice showed negative attitude towards HIV/AIDS, with $63 \%$ with B.Pharm qualification showing a positive attitude towards HIV services. A correlation between respondents' attitude and their readiness towards HIV services was seen to be statistically significant $(p<0.05)$.

Impact of demographic characteristics on the respondents' level of readiness in HIV/AIDS activities in their 
Table 4 Involvement of respondents based on demographic characteristics

\begin{tabular}{|c|c|c|c|c|c|c|c|}
\hline Demographic Characteristics & $\begin{array}{l}\text { Low involvement } \\
\mathrm{n}(\%)\end{array}$ & $\begin{array}{l}\text { Moderate involvement } \\
\mathrm{n}(\%)\end{array}$ & $\begin{array}{l}\text { High involvement } \\
\mathrm{n}(\%)\end{array}$ & Mean & Std. deviation & Std. error & $p$ value \\
\hline \multicolumn{8}{|l|}{ Gender } \\
\hline Male & $93(59.6)$ & $25(69.4)$ & $4(40.0)$ & 38.15 & 15.58 & 1.41 & $0.15^{\mathrm{a}}$ \\
\hline Female & $63(40.4)$ & $11(30.6)$ & $6(60.0)$ & 34.55 & 19.62 & 2.20 & \\
\hline \multicolumn{8}{|l|}{ Age (Years) } \\
\hline$\leq 30$ & $17(10.9)$ & $5(10.9)$ & $1(10.0)$ & 41.50 & 13.93 & 2.90 & $0.01^{b}$ \\
\hline $31-40$ & $54(36.4)$ & $21(58.3)$ & $5(50.0)$ & 37.85 & 19.70 & 2.20 & $0.02^{b}$ \\
\hline $41-50$ & $35(22.4)$ & $9(25.0)$ & $1(10.0)$ & 36.57 & 15.56 & 2.30 & $0.05^{b}$ \\
\hline $51-60$ & $33(21.2)$ & $1(2.8)$ & $2(20.0)$ & 37.12 & 14.15 & 2.35 & $0.05^{b}$ \\
\hline$\geq 61$ & $17(10.9)$ & $0(0.0)$ & $1(10.0)$ & 25.25 & 16.95 & 4.00 & Referent \\
\hline \multicolumn{8}{|l|}{ No of employees } \\
\hline$\leq 5$ staff & $97(62.2)$ & $27(75.0)$ & $3(30.0)$ & 35.93 & 16.47 & 1.46 & $0.34^{\mathrm{b}}$ \\
\hline 6-10 staff & $47(30.1)$ & $8(22.2)$ & $5(50.0)$ & 36.95 & 19.15 & 2.47 & $0.45^{b}$ \\
\hline 11-15 staff & $6(3.8)$ & $1(2.8)$ & $0(0.0)$ & 40.26 & 11.57 & 4.37 & $0.89^{b}$ \\
\hline$\geq 15$ staff & $6(3.8)$ & $0(0.0)$ & $2(20.0)$ & 44.32 & 21.42 & 7.57 & Referent \\
\hline \multicolumn{8}{|l|}{ Years of practice (Years) } \\
\hline$\leq 5$ & $40(25.6)$ & $8(22.2)$ & $1(10.0)$ & 36.18 & 16.75 & 2.39 & $0.99^{b}$ \\
\hline $6-10$ & $42(26.9)$ & $13(36.1)$ & $4(40.0)$ & 36.36 & 18.87 & 2.46 & $0.99^{b}$ \\
\hline $11-15$ & $22(14.1)$ & $8(22.2)$ & $0(0.0)$ & 38.18 & 14.99 & 2.74 & $0.85^{\mathrm{b}}$ \\
\hline $16-19$ & $9(5.8)$ & $4(11.1)$ & $1(10.0)$ & 42.21 & 16.59 & 4.43 & $0.52^{b}$ \\
\hline$\geq 20$ & $43(27.6)$ & $3(8.3)$ & $4(40.0)$ & 35.27 & 17.87 & 2.53 & Referent \\
\hline \multicolumn{8}{|l|}{ Qualifcation(s) } \\
\hline B. Pharm & $98(62.8)$ & $22(61.1)$ & $5(50.0)$ & 35.85 & 16.78 & 1.5 & $<0.001^{\mathrm{b}}$ \\
\hline M. Pharm & $32(66.7)$ & $13(36.1)$ & $3(30.0)$ & 41.67 & 17.27 & 2.39 & $0.01^{b}$ \\
\hline Pharm. D & $22(14.1)$ & $1(2.8)$ & $0(0.0)$ & 26.48 & 12.53 & 2.61 & $<0.001^{b}$ \\
\hline FPC.Pharm & $3(1.9)$ & $0(0.0)$ & $0(0.0)$ & 39.39 & 10.50 & 6.06 & $0.06^{\mathrm{b}}$ \\
\hline MBA & $1(0.6)$ & $0(0.0)$ & $2(20.0)$ & 69.69 & 21.00 & 12.12 & Referent \\
\hline
\end{tabular}

community pharmacies are presented in Table 6 with the readiness level grouped into low, moderate and high readiness. Both gender groups were highly ready to offer HIV services in their premise with a mean score of $86.8 \pm$ SD (15.48) for female and $87.66 \pm$ SD (15.96) for male. Encouragingly, majority of those with B.Pharm qualification were highly ready to offer HIV services $85.26 \pm \mathrm{SD}(11.39)$. Table 7 shows the impact of demographic characteristics on the respondents' skill in HIV/ AIDS activities in their community pharmacies with skill grouped into low, moderate and high skilled with an effect size of 0.07 for the demographic characteristics $F(4,199)=3.75, p<0.001$. On the age distribution, post hoc analysis using Dunnett's test indicated that the mean knowledge score for $>61$ years age group $(\mathrm{M}=25.56 \pm \mathrm{SD}(34.85)$ was significantly different from those of $51-60$ years $(\mathrm{M}=51.31 \pm(\mathrm{SD}) 32.98, p=0.04)$. Also, the distribution of number of employee using post hoc analysis revealed that the mean skill score for employee $\geq 15(\mathrm{M}=72.50 \pm \mathrm{SD}(44.96)$ was significantly different from those $\leq 5(\mathrm{M}=38.15 \pm \mathrm{SD}$ (38.71), $p=0.03)$ and those of $6-10(\mathrm{M}=36.10 \pm \mathrm{SD}(35.67)$, $\mathrm{p}=0.03)$. A correlation between the respondents' skills and their involvement in HIV services was seen to be statistically significant $(p<0.05)$.

\section{Discussion}

This study assessed community pharmacists' knowledge and attitude together with their present level of involvement in HIV/AIDS care and services including their willingness and readiness to participate in the care and services. HIV/AIDS knowledge among the surveyed community pharmacists was perceived to be high with a somewhat attitude towards the involvement of the pharmacists in HIV/AIDS care and services. Although they are currently not fully involved in this care, they were assessed to be ready to take up these services however; 
Table 5 Attitude of respondents based on demographic characteristics

\begin{tabular}{|c|c|c|c|c|c|c|}
\hline Demographic characteristics & $\begin{array}{l}\text { Negative Attitude } \\
\mathrm{n}(\%)\end{array}$ & $\begin{array}{l}\text { Positive attitude } \\
\mathrm{n}(\%)\end{array}$ & Mean & Std. deviation & Std. error & $p$ value \\
\hline \multicolumn{7}{|l|}{ Gender } \\
\hline Male & 67 (56.3) & $56(66.7)$ & 58.94 & 20.05 & 1.81 & $0.08^{\mathrm{a}}$ \\
\hline Female & $52(43.7)$ & $28(33.3)$ & 53.95 & 18.79 & 2.11 & \\
\hline \multicolumn{7}{|l|}{ Age (Years) } \\
\hline$\leq 30$ & $13(10.9)$ & $10(11.9)$ & 55.07 & 22.72 & 4.74 & $0.55^{\mathrm{b}}$ \\
\hline $31-40$ & $42(35.3)$ & $38(42.2)$ & 57.71 & 17.58 & 1.97 & $0.16^{\mathrm{b}}$ \\
\hline $41-50$ & $26(21.8)$ & 19 (22.6) & 59.26 & 19.96 & 2.98 & $0.12^{\mathrm{b}}$ \\
\hline $51-60$ & $23(19.3)$ & $14(16.7)$ & 58.11 & 21.38 & 3.52 & $0.19^{\mathrm{b}}$ \\
\hline$\geq 61$ & $15(12.6)$ & $3(3.6)$ & 48.15 & 19.71 & 4.65 & Referent \\
\hline \multicolumn{7}{|l|}{ No of employees } \\
\hline$\leq 5$ staff & $89(74.8)$ & $39(46.4)$ & 52.73 & 18.21 & 1.61 & $0.09^{b}$ \\
\hline $6-10$ staff & $25(21.0)$ & $35(41.7)$ & 64.44 & 19.03 & 2.46 & $0.96^{\mathrm{b}}$ \\
\hline $11-15$ staff & $4(3.4)$ & $3(3.6)$ & 59.52 & 26.97 & 10.19 & $0.72^{\mathrm{b}}$ \\
\hline$\geq 15$ staff & $1(0.8)$ & $7(8.3)$ & 66.67 & 23.57 & 8.33 & Referent \\
\hline \multicolumn{7}{|l|}{ Years of Practice (Years) } \\
\hline$\leq 5$ & $34(26.8)$ & $15(17.9)$ & 54.08 & 16.85 & 2.41 & $0.66^{\mathrm{b}}$ \\
\hline $6-10$ & $27(22.7)$ & $32(38.1)$ & 59.04 & 19.41 & 2.53 & $1.00^{\mathrm{b}}$ \\
\hline $11-15$ & $18(15.1)$ & $12(14.3)$ & 56.11 & 20.75 & 3.79 & $0.97^{\mathrm{b}}$ \\
\hline $16-19$ & $8(6.7)$ & $6(7.1)$ & 54.76 & 23.05 & 6.16 & $0.94^{b}$ \\
\hline$\geq 20$ & $32(26.9)$ & 19 (22.6) & 58.50 & 21.80 & 2.97 & Referent \\
\hline \multicolumn{7}{|l|}{ Qualification(s) } \\
\hline B. Pharm & $75(63.0)$ & $51(60.7)$ & 55.69 & 19.80 & 1.76 & $0.29^{\mathrm{b}}$ \\
\hline M. Pharm & $30(21.2)$ & $18(21.4)$ & 5.66 & 20.26 & 2.93 & $0.34^{\mathrm{b}}$ \\
\hline Pharm. D & $12(10.1)$ & $11(13.1)$ & 61.59 & 15.44 & 3.22 & $0.63^{\mathrm{b}}$ \\
\hline FPC.Pharm & $1(0.8)$ & $2(2.4)$ & 66.67 & 28.87 & 16.67 & $0.96^{\mathrm{b}}$ \\
\hline MBA & $1(0.8)$ & $1(0.8)$ & 72.22 & 25.46 & 14.70 & Referent \\
\hline
\end{tabular}

their perceived skills in carrying out these services were poor.

Community pharmacists as the most accessible healthcare professional to the public have been adjudged to be in a better position for early detection and management of chronic diseases together with the other healthcare professionals [26]. Chronic disease screenings, counselling on the appropriate use of medicines, life style changes advocacy, working with other healthcare professionals and general provision of pharmaceutical care services to these patients are some of the identified areas where community pharmacists could help improve the quality of life of patients with chronic diseases [5]. HIV/ AIDS is a chronic disease of concern because of its high morbidity and mortality rate. Early detection of HIV and timely initiation of antiretroviral therapy is crucial in achieving the vision of controlling the virus which will help prevent transmission and HIV/AIDS associated deaths [6]. Achieving this is primarily hinged on ensuring universal access to the lifesaving medications and access to other HIV prevention services [4] including counselling and testing. Hence, the use of more peripheral health professional settings including the community pharmacists could be optimally utilized to improve and enhance access to HIV care and services. Although the Global HIV/AIDS initiative Nigeria (GHAIN), launched a programme in 2007 led by Howard University Pharmacist and Continuing Education centre (HU-PACE) through the Pharmacists Council of Nigeria's (PCN) pharmacy continuing education on skill enhancement among others, the involvement of community pharmacists in HIV/AIDS care and services are still uncertain.

The result of this study showed a high knowledge of HIV by the community pharmacists similar to a study in Mexico [27] but, contrary to studies in India [14] and New York [28] that found low HIV knowledge by community pharmacists. This high knowledge may be 
Table 6 Readiness of respondents based on demographic characteristics

\begin{tabular}{|c|c|c|c|c|c|c|c|}
\hline Demographic characteristics & $\begin{array}{l}\text { Low readiness } \\
\mathrm{n}(\%)\end{array}$ & $\begin{array}{l}\text { Moderately ready } \\
\text { n (\%) }\end{array}$ & $\begin{array}{l}\text { Highly ready } \\
\text { n (\%) }\end{array}$ & Mean & Std. deviation & Std. error & $p$ value \\
\hline \multicolumn{8}{|l|}{ Gender } \\
\hline Male & $2(66.7)$ & $13(61.9)$ & $110(61.1)$ & 87.66 & 15.96 & 1.42 & $0.71^{\mathrm{a}}$ \\
\hline Female & $1(33.3)$ & $8(38.1)$ & $70(38.9)$ & 86.80 & 15.48 & 1.74 & \\
\hline \multicolumn{8}{|l|}{ Age (Years) } \\
\hline$\leq 3$ & $0(0.0)$ & $2(9.5)$ & $21(11.7)$ & 91.93 & 14.17 & 2.96 & $0.36^{b}$ \\
\hline $31-40$ & $1(33.3)$ & $6(28.6)$ & $73(40.6)$ & 87.14 & 15.01 & 1.68 & $0.92^{b}$ \\
\hline $41-50$ & $2(66.7)$ & $2(9.5)$ & $41(22.8)$ & 89.21 & 16.45 & 2.45 & $0.99^{b}$ \\
\hline $51-60$ & $0(0.0)$ & $8(38.1)$ & $30(16.7)$ & 83.83 & 16.66 & 2.70 & $0.99^{b}$ \\
\hline$\geq 61$ & $0(0.0)$ & $3(14.3)$ & $15(8.3)$ & 84.92 & 16.60 & 3.91 & Referent \\
\hline \multicolumn{8}{|l|}{ No of employee } \\
\hline$\leq 5$ staff & $2(100)$ & $21(100)$ & $105(58.3)$ & 84.83 & 17.38 & 1.53 & $0.68^{b}$ \\
\hline $6-10$ staff & $0(0.0)$ & $0(0.0)$ & $60(33.3)$ & 91.67 & 10.94 & 1.41 & $0.92^{b}$ \\
\hline $11-15$ staff & $0(0.0)$ & $0(0.0)$ & $7(3.9)$ & 93.88 & 11.24 & 4.25 & $0.83^{b}$ \\
\hline$\geq 15$ staff & $0(0.0)$ & $0(0.0)$ & $8(4.4)$ & 89.29 & 14.79 & 5.23 & Referent \\
\hline \multicolumn{8}{|l|}{ Years of Practice (Years) } \\
\hline$\leq 5$ & $1(33.3)$ & $6(26.6)$ & $42(23.3)$ & 86.88 & 16.71 & 2.39 & $0.96^{\mathrm{b}}$ \\
\hline $6-10$ & $0(0.0)$ & $1(4.8)$ & $57(31.7)$ & 92.12 & 11.41 & 1.50 & $0.07^{b}$ \\
\hline $11-15$ & $2(66.7)$ & $6(28.6)$ & $23(12.8)$ & 80.18 & 19.41 & 3.49 & $0.44^{b}$ \\
\hline $16-19$ & $0(0.0)$ & $0(0.0)$ & $14(7.8)$ & 92.86 & 10.85 & 2.90 & $0.29^{b}$ \\
\hline$\geq 20$ & $0(0.0)$ & $8(21.0)$ & $44(24.4)$ & 85.16 & 16.00 & 2.21 & Referent \\
\hline \multicolumn{8}{|l|}{ Qualification(s) } \\
\hline B. Pharm & $2(66.7)$ & $17(80.1)$ & $108(60)$ & 85.26 & 16.39 & 1.45 & $0.84^{\mathrm{b}}$ \\
\hline M. Pharm & $1(33.3)$ & $1(4.8)$ & $46(25.6)$ & 90.18 & 13.87 & 2.00 & $1.00^{\mathrm{b}}$ \\
\hline Pharm. D & $0(0.0)$ & $3(14.3)$ & $20(11.1)$ & 91.30 & 15.97 & 3.33 & $1.00^{\mathrm{b}}$ \\
\hline FPC. Pharm & $0(0.0)$ & $0(0.0)$ & $3(1.7)$ & 95.24 & 8.25 & 4.76 & $0.95^{b}$ \\
\hline MBA & $0(0.0)$ & $0(0.0)$ & $3(1.7)$ & 90.48 & 8.25 & 4.76 & Referent \\
\hline
\end{tabular}

attributed to the basic knowledge gained in the universities and through other trainings like the mandatory continuing professional development (MCPD) as well as easy access to information on the internet. Michael and Kristin observed in their study that internet had a positive impact on knowledge level of pharmacists [29]. The incorporation of modules of HIV/AIDS into the Pharmacists Council of Nigeria (PCN) coordinated mandatory continuing professional development (MCPD) for pharmacists in Nigeria may have contributed to the observed high knowledge level. The inability of most of the pharmacists to correctly answer the question on WHO clinical staging of HIV/AIDS was surprising since Nigeria adopted the WHO staging and this has been the basis for the initiation of ART in adults and paediatrics in Nigeria. Further analysis of the pharmacists' knowledge using post hoc showed that the younger community pharmacists had a significant higher scores than the older ones which still points to the importance of internet in their knowledge base. Moreover, the incorporation of more client based studies in the current curriculum especially with the introduction of pharmaceutical care may have contributed to this observed difference [30]. More so, HIV/AIDS may not have attracted much attention when the present older pharmacists were in school and hence, a possible reduction in their interest on the topic which may have translated to their poorer knowledge. This was further buttressed by the lower knowledge seen among people that have been in practice for a longer time compared to those newer in practice.

Majority of the pharmacists believed that they have major roles to play in the provision of HIV services although they are currently not involved. This may be in line with the FIP statement which recognized pharmacists as stakeholders in the management of chronic diseases as these diseases including HIV/AIDS often require long time use of medicines [26]. Since community pharmacists have been involved in providing pharmaceutical care and in 
Table 7 Skill of respondents based on demographic characteristics

\begin{tabular}{|c|c|c|c|c|c|c|c|}
\hline Demographic characteristics & $\begin{array}{l}\text { Low skill } \\
\mathrm{n}(\%)\end{array}$ & $\begin{array}{l}\text { Moderately skillful } \\
\mathrm{n}(\%)\end{array}$ & $\begin{array}{l}\text { Highly skilled } \\
\mathrm{n}(\%)\end{array}$ & Mean & Std. deviation & Std. error & $p$ value \\
\hline \multicolumn{8}{|l|}{ Gender } \\
\hline Male & 79 (59.4) & $8(80.0)$ & $37(60.7)$ & 41.45 & 36.66 & 3.29 & $0.31^{a}$ \\
\hline Female & $54(40.6)$ & $2(20.0)$ & $24(39.3)$ & 35.88 & 40.31 & 4.51 & \\
\hline \multicolumn{8}{|l|}{ Age (Years) } \\
\hline$\leq 30$ & $12(9.0)$ & $3(30.0)$ & $8(13.1 \%)$ & 49.13 & 41.56 & 8.66 & $0.12^{b}$ \\
\hline $31-40$ & $61(45.9)$ & $1(10.0)$ & $18(29.5 \%)$ & 29.73 & 35.36 & 3.99 & $0.97^{b}$ \\
\hline $41-50$ & $26(19.5)$ & $1(10.0)$ & $18(29.5 \%)$ & 46.44 & 41.35 & 6.16 & $0.12^{b}$ \\
\hline $51-60$ & $20(15.0)$ & $5(50.0)$ & $13(21.3 \%)$ & 51.31 & 32.98 & 5.35 & $0.04^{b}$ \\
\hline$\geq 61$ & $14(10.5)$ & $0(0.0)$ & $4(6.6 \%)$ & 25.56 & 34.85 & 8.21 & Referent \\
\hline \multicolumn{8}{|l|}{ Number of employees } \\
\hline$\leq 5$ staff & $86(64.7)$ & $4(40.0)$ & $40(65.6)$ & 38.15 & 38.71 & 3.35 & $0.03^{b}$ \\
\hline $6-10$ staff & $41(30.8)$ & $5(50.0)$ & $13(21.3)$ & 36.10 & 35.67 & 4.64 & $0.03^{b}$ \\
\hline $11-15$ staff & $4(3.0)$ & $0(0.0)$ & $3(4.9)$ & 48.57 & 38.91 & 14.71 & $0.39^{b}$ \\
\hline$\geq 15$ staff & $2(1.5)$ & $1(10.0)$ & $5(8.2)$ & 72.50 & 44.96 & 15.90 & Referent \\
\hline \multicolumn{8}{|l|}{ Years of Practice (Years) } \\
\hline$\leq 5$ & $33(24.8)$ & $3(30.0)$ & $12(19.7)$ & 33.54 & 38.4 & 5.54 & $0.36^{\mathrm{b}}$ \\
\hline $6-10$ & $40(30.1)$ & $0(0.0)$ & $19(31.1)$ & 38.98 & 38.63 & 5.03 & $0.82^{b}$ \\
\hline $11-15$ & $28(21.1)$ & $0(0.0)$ & $3(4.9)$ & 26.77 & 29.14 & 5.23 & $0.11^{b}$ \\
\hline $16-19$ & $3(2.3)$ & $3(30.0)$ & $8(13.1)$ & 65.71 & 35.24 & 9.42 & $0.22^{b}$ \\
\hline$\geq 20$ & $29(21.8)$ & $4(40.0)$ & 19 (31.4) & 45.91 & 39.53 & 5.48 & Referent \\
\hline \multicolumn{8}{|l|}{ Qualification(s) } \\
\hline B. Pharm & $84(63.2)$ & $5(50.0)$ & $38(62.3)$ & 38.43 & 37.97 & 3.37 & $0.47^{b}$ \\
\hline M.Pharm & $29(21.8)$ & $5(50.0)$ & $14(23.0)$ & 42.50 & 38.67 & 5.58 & $0.60^{\mathrm{b}}$ \\
\hline Pharm. D & $18(13.5)$ & $0(0.0)$ & $5(8.2)$ & 31.17 & 39.04 & 8.14 & $0.33^{b}$ \\
\hline FPC. Pharm & $1(0.8)$ & $0(0.0)$ & $2(3.3)$ & 56.67 & 49.33 & 28.48 & $0.99^{b}$ \\
\hline MBA & $1(0.8)$ & $0(0.0)$ & $2(3.3)$ & 63.33 & 11.55 & 6.67 & Referent \\
\hline
\end{tabular}

${ }^{\mathrm{a}}$-test was applied, ${ }^{\mathrm{b}}$ Dunnet test was applied, $n=205$

identifying and resolving drug therapy problems including counseling in other chronic diseases, they may have believed that HIV/AIDS should not be an exception hence, the positive outlook. Although most of the community pharmacists are willing to use their premise for these services, they are currently seen not to be involved in the provision of the services with an involvement score of 36.7\%. The Global HIV/AIDS imitative Nigeria (GHAIN) in 2007 lunched a program led by Howard University Pharmacist and Continuing Education center (HU-PACE) in some states in Nigeria centered on getting the community pharmacists involved in the provision of care to HIV/ AIDS patients but, the program could be adjudged not to be a success. This may be due to the program design and execution mode as the service delivery in the said project was mainly through pharmacist volunteer scheme [31]. Most HIV care services in Nigeria is offered freely through government owned hospitals and for community pharmacists who are in the private sector, without adequate motivation with respect to reimbursement and incentives, their attitude towards providing such services may dwindle because money is needed to maintain the facilities and possibly employ more pharmacists. Since remunerations for the pharmacists were not captured in the pilot program, this may have affected their acceptance of the program and hence, their present low level of involvement seen in this study. This study further found that most of the community pharmacists indicted that reimbursement and incentives will motivate them to offer HIV services in their respective premises. Although the study found some involvement level, this may be just the ones carried out to keep their customers. Moreover, the major area where they were seen to be much involved was in the stocking of condoms which may be for the purpose of family planning. Similar to the findings with the impact of demography on knowledge, the younger pharmacists showed higher level of involvement with HIV services than the older pharmacists which correlates with their knowledge base. This is similar 
to what was observed in a report on HIV/AIDS services delivery through pharmacist volunteer scheme carried out in Nigeria by Onuoha et al., [31]. Surprisingly, community pharmacists with master's in business administration showed higher involvement than those with B. Pharm and even Pharm. D. However, the findings of Daly et al., [32] in their study in the University of Buffalo, New York may explain this observation.

Some of the basic requirements by WHO for a facility to be involved in offering HIV care were adequate space, a counselling section with auditory and visual privacy to maintain privacy and confidentiality, as well as a standby generator [33]. These coincidentally form part of the basic requirements for the registration of community pharmacy premises in Nigeria, and as such a boost for the readiness of community pharmacists to offer HIV services [34]. Majority of the community pharmacies used in this study met with these criteria, signifying their readiness to take up such services. Furthermore, about two-third of the pharmacist were willing to use their premise for the provision of HIV services. This is similar to a study carried out in India which showed that community pharmacists in India were highly willing to participate in the care of HIV infected persons [14]. This high willingness to participate in HIV care was also seen in a recent survey conducted by SIDHAS to scale up community based ARV refill in Nigeria [9]. Irrespective of the community pharmacists' high willingness and readiness to care for the HIV/AIDS patients, they still showed poor skills. This calls for urgent need for further training if they must be involved. Meanwhile, most of the surveyed pharmacists probably recognised this and recommended that training will further enhance their skills and willingness to participate in HIV care and services.

There are a number of limitations in this study. The convenient use of only community pharmacists that attended meetings for the survey may not be a true representative of the population and may not have allowed for an even distribution of the pharmacists according to their practice area. Secondly, the sample size used and the use of only one geo-political zone in Nigeria for the study may not allow for a generalization of the community pharmacists' views to the entire country. The pharmacists may be bias in assessing their skills since they were asked to rate themselves. Furthermore, the number of items used to assess readiness may not be sufficient to measure pharmacists' readiness to offer HIV services. Despite these limitations however, this research could serve as a pilot to a more detailed and a larger national survey that will improve community pharmacists' involvement and participation in the care of people living with HIV/AIDS which will help optimize their roles as well as improve the health of these patients.

\section{Conclusion}

This study observed high knowledge but, low perceived skills of community pharmacists in the study area to care for HIV/AIDS patients. Although they are currently not involved in these services, their high willingness and readiness to get involved is a pointer that training and retraining programs will get them to a better feat of providing these services. Even though a few of them already offer HIV care services, more is needed in the aspects of refill of ARVs, medication treatment and monitoring of ARVs, adherence counseling, social responsibility to HIV clients, stocking of ARVs and HIV test kits and provision of Post Exposure Prophylaxis (PEP). This will help combat some of the hindrances to adherence on HIV care seen in some studies such as lack of accessible HIV care and not having adequate funds to transport to HIV care facilities. We therefore recommend that HIV/AIDS policy makers in Nigeria should expand the coverage of HIV/AIDS services by involving and training the community pharmacists to improve their skills in offering these services.

\section{Additional file}

Additional file 1: Study Instrument. (DOCX $20 \mathrm{~kb}$ )

\begin{abstract}
Abbreviations
GHAIN: The Global HIV/AIDS initiative Nigeria; HU-PACE: Howard University Pharmacist and Continuing Education center; MCPD: Mandatory continuing professional development; PCN: Pharmacists Council of Nigeria; PEP: Post exposure prophylaxis; SIDHAS: Strengthening Integrated Delivery of HIV/AIDS services
\end{abstract}

\section{Acknowledgments}

I wish to acknowledge the officers of the Pharmacists Council of Nigeria in the five states of the south east geographical zone of Nigeria for their assistance especially, in the provision of number of registered community pharmacist used.

Funding

This research was not funded by any funding body.

Availability of data and materials

Available on request.

Authors' contributions

SON and AN designed the study. AN was responsible for data collection. SON and MUA analysed and interpreted the data. SON and AN drafted the manuscript. All authors reviewed and approved the manuscript.

\section{Ethics approval and consent to participate}

Ethical approval was obtained from the ethics committee of Nnamdi Azikiwe University Teaching Hospital, Nnewi, Anambra state, Nigeria. Oral consent was obtained from participants before administering the questionnaire. Participants' data were kept confidential.

Consent for publication

Not applicable.

Competing interests

The authors declare that they have no competing interests. 


\section{Publisher's Note}

Springer Nature remains neutral with regard to jurisdictional claims in published maps and institutional affiliations.

Received: 23 March 2017 Accepted: 11 October 2017

Published online: 02 November 2017

\section{References}

1. HIV factsheet. November 2016. http://www.unaids.org/en/resources/factsheet.

Accessed 22 Jan 2017

2. AVERT. Global information and esucation on HIV and AIDS: HIV and AIDS in sub-Saharan Africa. https://www.avert.org/infographics/hiv-andaids-subsaharan-africa. Accessed 28 Jan 2017.

3. Wanyenze RK, Kamya MR, Fatch R, Mayanja-Kizza H, Baveewo S, Bangsberg DR, et al. Abbreviated HIV counseling and testing and enhanced referral to care in Uganda: a factorial randomized control trial. Lancet Glob Health. 2013;1(3):e137-45.

4. UNAIDS. Access to Antiretroviral therapy in Africa. Status report on progress towards the 2015 target. UNAIDS; Geneva, 2014. http://www.unaids.org/ sites/default/files/media_asset/20131219_

AccessARTAfricaStatusReportProgresstowards2015Targets en_0.pdf. Accessed 14 July 2016

5. Leta TH, Sandoy IF, Fylkesnes K. Factors affecting voluntary HIV counselling among men in Ethiopia: a cross sectional survey. BMC Public Health. 2012;12:438.

6. UNAIDS factsheet 2015. http://www.aidsdatahub.org/sites/default/files/ publication/UNAIDS_fact_sheet_2015.pdf. Accessed 3 May 2016.

7. Ojeme V. 747,000 HIV patients under ART treatment in Nigeria-NACA report. Vanguard News. $26^{\text {th }}$ September, 2015. https://www.vanguardngr.com/ 2015/09/747000-hiv-patients-under-art-treatment-in-nigeria-naca/. Accessed 24 June 2016.

8. UNAIDS. Joint United Nations Programme on HIV/AIDS 2015, Switzerland. Unaids.org. Accessed 15 Dec 2016.

9. Fhi 360. Community based model of differentiated care for stable patients on antiretroviral therapy to a good start in Nigeria 2016 http://insidenigeria. org/community-based-model-of-differentiated-care-for-stable-patients-onantiretroviral-therapy-art-off-to-a-good-start-in-nigeria/. Accessed 22 Feb 2017

10. WHO. HIV/AIDS fact sheet. Updated November, 2015. http://www.who.int mediacentre/factsheets/fs360/en/. Accessed 29 July 2016.

11. WHO. HIV/AIDS: HIV testing services. http://www.who.int/hiv/topics/vct/en/. Accessed 20 Aug 2016

12. Royal Pharmaceutical Society Pharmacy in a new age: the new horizon. London: the Society; 1996b. p10-11

13. WHO/FIP. Developing pharmacy practice: afocus on patient care. Hague: World Health Organisation and International Pharmaceutical Federation; 2006.

14. Gupta A, Sane SS, Gurbani A, Bollinger RC, Mehendale SM, Godbole SV. Stigmatizing attitudes and low levels of knowledge but high willingness to participate in HIV management: a community- based survey of pharmacies in Pune, India. BMC Public Health. 2010;10:517.

15. Gorostiza I, Elizondo LI, Braceras IL. HIV/AIDS screening program in community pharmacies in the Basque Country (Spain). Gac Sanit. 2013;27(2):164-6.

16. Ndukwe $\mathrm{H}$. Future dimensions in pharmacy practice for developing countries: a Nigerian perspective: novel Sci inter. J Pharm Sci. 2012;1:9-10.

17. Hyginus NC. Foreign Missionary Background and Indigenous Evangelization in Igboland: Igboland and the Igbo people of Nigeria. 2013. Transaction Publishers, USA.p.17.ISBN 3-8258-4964-3.

18. NPC. Population and housing census of the Federal Republic of Nigeria. National Population Commission, Abuja, Nigeria. 2006. http://www. population.gov.ng/. Accessed 6 Jan 2016.

19. Ademiluyi IS, Aluo-Arowolo SO. Infrastructural distribution of healthcare services in Nigeria: an overview. J Geogr Reg Plann. 2009:2(5):104-10.

20. CRS. Research Aid: Sample Size calculator. Creative Resarch system. http:// www.surveysystem.com/sscalc.htm. Accessed 23 Aug 2016.

21. World Health Organisation. Operations Manual for Delivery of HIV Prevention, Care and Treatment at Primary Health Centres in HighPrevalence, Resource-Constrained Settings: edition 1 for field-testing and country adaptation. World Health organization, 2008. http://www.who.int/ hiv/pub/imai/om.pdf. Accessed 27 July 2016.
22. American Society of Health-System Pharmacists. ASHP statement on the Pharmacists role in the care of patients with HIV infection. AM J Health-Syst Pharm. 2003;59(5):447-52. http://www.ncbi.nlm.nih.gov/pubmed/14531248.

23. Global HIV/AIDS Initiative Nigeria. GHAIN Support To HIV-Related Pharmaceutical Services In Nigeria, End Of Project Monograph, 2007.https:// www.fhi360.org/sites/default/files/media/documents/ GHAIN\%20support\%20to\%20HIV-related\%20pharmaceutical\%20services.pdf.

24. $\mathrm{FMoH}$. Training manual for Doctors on the use of Antiretroviral Drugs in Nigeria. Lagos, NIMR: Federal Ministry of Health; 2005.

25. FMoH. Training manual for Pharmacist on the use of Antiretroviral Drugs in Nigeria. Lagos, NIMR: Federal Ministry of Health; 2005.

26. Federation Internationale Pharmacists. FIP 2006 Statement of policy on the role of the pharmacist in the prevention and treatment of chronic disease. 2005. https://www.fip.org/www/uploads/database_file.php?id=274\&table_ $\mathrm{id}=$. Assessed 5 Mar 2017

27. Pineda LJ, Mercier R, Dilworth T, landiorio M, Rankin S, Jakeman B. Evaluating community pharmacists' HIV testing knowledge: a cross sectional survey. J Am Pharm Assoc. 2015;55:424-8. https://doi.org/10.1331/JAPhA. 2015.14139.

28. Jodlowski TZ, Sym D, Conry J, Kanmaz T. Antiretroviral medication knowledge among New York state pharmacists: room for improvement. J Pharm Pract. 2010:23(5):507-10

29. Brown MC, Janke KK. Impact of an internet -based smoking cessation educational module on pharmacists' knowledge and practice. Am J Pharm Edu. 2003; https://doi.org/10.5688/aj674107.

30. Udeogaranya PO, Ukwe CV, Ekwunife Ol. Assessment of attitudes of University of Nigeria students towards pharmaceutical care. Pharm Pract (internet). 2009;7(3):145-9.

31. Onuoha C, Agu AK, Oqua D, Omeh OO, Alfa IM, Ekechukwu N. et al. Enhancing human resources for HIV/ADS services delivery through pharmacist volunteer scheme: case report of global HIV/AIDS initiative Nigeria. Public Health Res. 2014; doi:https://doi.org/10.5923/j.phr.20140401.04.

32. Daly CJ, Fiebelkorn KD, O'Brien $E_{1}$ Jacobs DM. Impact of a Master in Business Administration (MBA) Degree on the career of a Pharmacist. University at Buffalo. 2015. http://www.aacp.org/meetingsandevents/AM/2015/ Documents/abstracts/ResearchEdu/Pharm_Practice/Impact_of_a_Master_ business.pdf. Accessed 5 Mar 2017

33. WHO. WHO Standards for quality HIV care: a tool for quality assessment, improvement, and accreditation: Report of a WHO consultation meeting onthe accreditation of health service facilities for HIV care, 10-11 May 2004 Geneva, Switzerland.http://www.who.int/hiv/pub/prev_care/en/ standardsquality.pdf. Accessed 23 June 2016.

34. Pharmacists' council of Nigeria. Four part compendium of minimum standards of pharmaceutical care in Nigeria, Abuja 2005.

\section{Submit your next manuscript to BioMed Central and we will help you at every step:}

- We accept pre-submission inquiries

- Our selector tool helps you to find the most relevant journal

- We provide round the clock customer support

- Convenient online submission

- Thorough peer review

- Inclusion in PubMed and all major indexing services

- Maximum visibility for your research

Submit your manuscript at www.biomedcentral.com/submit 